\title{
Do dietary stresses affect the immune system of Periplaneta americana (Blattaria: Blattidae)?
}

\author{
J. P. Duarte ${ }^{\mathrm{a} *}$ (1), C. E. Silva ${ }^{\mathrm{b}}$ (D), P. B. Ribeiro and M. C. Cárcamo \\ ${ }^{a}$ Laboratório de Entomologia, Departamento de Microbiologia e Parasitologia, Instituto de Biologia, \\ Universidade Federal de Pelotas - UFPel, CEP 96010-900, Pelotas, RS, Brasil \\ 'Laboratório de Parasitologia, Departamento de Microbiologia, Immunologia e Parasitologia, Instituto de Ciências Básicas \\ da Saúde, Universidade Federal de Rio Grande do Sul - UFRGS, CEP 90035-190, Porto Alegre, RS, Brasil \\ *e-mail: juceliod@hotmail.com
}

Received: January 11, 2018 - Accepted: June 26, 2018 - Distributed: February 28, 2020

(With 3 figures)

\begin{abstract}
Stresses can be caused by multiple biotic and abiotic factors and their effects can affect both the biology and the immune system of insects. American cockroach - Periplaneta americana (Linnaeus, 1758) (Blattaria: Blattidae) -besides being an excellent model species, has great medical importance because it can act as a mechanical vector of several pathogens. This study aimed to evaluate the influence of starvation, dehydration and both stresses on weight, and total and differential haemocyte count in P. americana adults. Each specimen was isolated in glass flasks containing or not food and/or water. They were weighed periodically. Another group received water for $24 \mathrm{~h}$ after the end of stress period. In the immunologic bioassay, we counted their haemocytes after the final weighing. All stresses reduced the insect weight, especially when the stresses were combined. Females of the control group gained weight and males had it unaltered. Different stress conditions and time did not influence on total haemocyte count. Insects without food and water had the proportion of prohaemocytes increased and plasmatocytes decreased. This study can serve as a basis of further studies of bioecology, behaviour and the ability of resisting insecticides, besides serving as a model to studies in other insect species.
\end{abstract}

Keywords: body mass, cockroach, dehydration, haemocytes, starvation.

\section{Estresses alimentares afetam o sistema immune de Periplaneta americana (Blattaria: Blattidae)?}

\section{Resumo}

Os estresses podem ser causados por múltiplos fatores bióticos e abióticos e seus efeitos podem afetar tanto a biologia como o sistema imune dos insetos. A barata-americana - Periplaneta americana (Linnaeus, 1758) (Blattaria: Blattidae) - além de ser uma excelente espécie modelo, tem grande importância médica, pois pode atuar como vetor mecânico de diversos patógenos. O objetivo desse estudo foi avaliar a influência da inanição, desidratação e ambos os estresses sobre o peso e o número total e diferencial de hemócitos em adultos de P. americana. Cada espécime foi isolado em frascos de vidro contendo ou não alimento e/ou água. Eles foram pesados periodicamente. Outro grupo recebeu água por $24 \mathrm{~h}$ após o término do período de estresse. Nos ensaios imunológicos, foram contados os seus hemócitos após a última pesagem. Todos os estresses reduziram o peso dos insetos, especialmente quando os estresses foram combinados. As fêmeas do grupo controle ganharam peso e os machos tiveram seu peso inalterado. As diferentes condições de estresse e tempo não influenciaram no número total de hemócitos. Os insetos sem alimento e água tiveram a proporção de pró-hemócitos aumentada e a de plasmatócitos reduzida. Esse estudo pode servir como base para estudos posteriores de bioecologia, comportamento e da habilidade de resistir aos inseticidas químicos, além de servir como modelo para estudos em outras espécies de insetos.

Palavras-chave: barata, desidratação, hemócitos, inanição, massa corporal.

\section{Introduction}

Multiples biotic and abiotic factors can cause stress in insects like overcrowding, pathogenic/parasitic infection, extreme temperatures, metamorphosis, mechanic injuries, chemical poisoning, starvation and others (Brey, 1994). Starvation and dehydration can impact the insect biology, affecting their growth, survival, longevity, reproduction, 
movements, gregarious habits and they can also decrease the production of energy to maintain these functions (Panizzi and Parra, 2009; Chapman, 2013).

Furthermore, the absence of these resources can weaken their immune system (Feder et al., 1997), either in haemocyte number (Sujatha and Dutta-Gupta, 1991; Richards and Edwards, 1999; Block and Stoks, 2008) or in prophenoloxidase activity (Siva-Jothy and Thompson, 2002; Block and Stoks, 2008). This impact on immune system makes the insect more susceptible to infections by microorganisms and disease development (Feder et al., 1997; Furlong and Groden, 2003; Lord, 2010).

Stresses can cause different effects in relation to insect species, thus, to evaluate stress impacts on invertebrate immunology is usually used model species. Among these species, we can find Periplaneta americana (Linnaeus, 1758) (Blattaria: Blattidae), insect that is easily reared in laboratory (Bressan-Nascimento et al., 2008; Vianna et al., 2011; Cárcamo et al., 2013), can resist up to 110 days without food and water (Duarte et al., 2015) and its biology is well-known (Vianna et al., 2000; Vianna et al., 2001; Bressan-Nascimento et al., 2008; Vianna et al., 2011).

Besides serving as an insect model, $P$. americana has a great medical importance since it can attend trash, bathrooms, sewers and drainage channels where it can get disease-causing agents to humans and to other animals (Kaya and Baran, 2015). These insects can reach great populations in urban environments and can act as a mechanical vector of several pathogens (Baumholtz et al., 1997), causing major problems to human and domestic animals' health.

Since $P$. americana is a very important pest in these environments, there is a need to understand its biology and ecology in several situations in order to help developing control strategies. Although there is a work evaluating the immune system of $P$. americana under starvation and dehydration (More and Sonawane, 1987), other study with more rigorous methodology and more extended evaluations is necessary. Thus, this work aimed to evaluate the influence of starvation, dehydration and both stresses on weight, and total and differential haemocyte count in P. americana adults.

\section{Materials and Methods}

\subsection{Maintenance of P. americana colonies}

Periplaneta americana adults were collected in Southern Brazil $\left(31^{\circ} 48^{\prime} \mathrm{S} ; 52^{\circ} 25^{\prime} \mathrm{W}\right)$ and raised for at least five generations in laboratory before the beginning of the experiment.

Colonies were maintained according to Vianna et al. (2001), differing only in the diet offered to nymphs and adults, which in this work was composed by meat meal and sugar (1: 1).

Throughout the experimental period, both stock and experimental individuals were kept in a climatic chamber $\left(25 \pm 2{ }^{\circ} \mathrm{C} ; 70 \pm 10 \% \mathrm{RH} ; 12 \mathrm{~L}: 12 \mathrm{D}\right)$.

\subsection{Weight change}

Periplaneta americana adults between three to seven days post-emergence were used. The initial weight was standardized in 0.9 to $1.2 \mathrm{~g}$ for females and 0.8 to $1.1 \mathrm{~g}$ for males.

We established four groups composed by 24 couples each: a) with food and water (control group); b) with water and no food (starvation); c) with food and no water (dehydration); and d) no food or water (both stresses). When food or water was available, they were offered ad libitum.

Each individual was isolated in glass flasks $(16 \mathrm{~cm}$ in height and $8 \mathrm{~cm}$ in diameter) covered by organza fabric. Diet and/or water, when present, were offered in plastic containers (1 cm in height and $2.5 \mathrm{~cm}$ in diameter) and refilled every three days.

For each group, eight couples were kept in these conditions for one of the three different periods: 10, 20 and 30 days. The specimens were weighed when they were isolated and again after the end of the period.

\subsection{Weight gain after rehydration}

Eight males and eight females were subjected to both stresses combined (starvation and dehydration) for one of the three different periods (10,20 and 30 days). The individuals also obeyed the same post-emergence period and weight aforementioned.

Each specimen was isolated in glass flasks and subjected to the same conditions than the previous bioassay. They were weighed to register their initial (before being isolated) and final weight (after the end of the experimental period). Then, the insects received water for $24 \mathrm{~h}$ and were weighed again to register the weight after the rehydration period.

\subsection{Total Haemocyte Count (THC) and Differential Haemocyte Count (DHC)}

We established five groups: a) with food and water (control group); b) with water and no food (starvation); c) with food and no water (dehydration); d) no food or water (both stresses) and e) no food or water for a determined period followed by $24 \mathrm{~h}$ of rehydration (both stresses - rehydrated). For each group, eight males and eight females were subjected to this condition for one of the three different periods (10, 20 and 30 days). The individuals also obeyed the same post-emergence period and weight previously described.

Each specimen was isolated in glass flasks and subjected to the same conditions than the previous bioassays. They were weighed to register their initial (before being isolated) and final weight (after the end of the experimental period). Insects of the rehydrated groups were also weighed after $24 \mathrm{~h}$ of rehydration.

After the final weighing, the insects were mechanically immobilized to analyse the haemolymph. Right metacoxa was amputated and, using an automatic micropipette, we collected $5 \mu$ l of haemolymph. The collected material was diluted in $15 \mu$ l of anticoagulant (Chalk and Suliaman, 1998) and placed in a Neubauer chamber to estimate the THC. 
To calculate the DHC, we collected $10 \mu$ l of haemolymph from the same cut and placed in a slide in order to make a blood smear. After drying, the slides were fixed and stained using a Differential Quik Stain Kit (Panótico Rápido LB ${ }^{\circledR}$ Laborclin $^{\circledR}$ ). Two hundred cells were counted under a light microscope to estimate the relative frequency of the cell types. The haemocyte characterization was based on a classification proposed by Wheeler (1963) and Ratcliffe and Price (1974).

After the haemolymph collection, the insects were sacrificed and discarded.

\subsection{Data analyses}

Insect weights and rates of weight change in different 10-day periods were evaluated by two-way Analysis of Variance (ANOVA) (time and stress group), which the means were compared by Tukey's test. Weight gains after rehydration were also evaluated by two-way ANOVA (time and sex), which the means were compared by Tukey's test.
To evaluate the THC, data were transformed by the square root of $\mathrm{x}$ to make them a normal distribution (Vieira, 2006). Similarly, before evaluating the DHC, data were transformed by the square root of $\mathrm{x}+0.5$ (Vieira, 2006). Then, data were evaluated by one-way ANOVA.

For all tests, we considered a significant level of $95 \%$.

\section{Results}

\subsection{Weight change}

The weight of females was significantly influenced by stress conditions $(\mathrm{F}=140.04 ; \mathrm{DF}=3 ; \mathrm{p}<0.001)$, but it was not influenced neither by stress time $(\mathrm{F}=2.40$; $\mathrm{DF}=2 ; \mathrm{p}=0.097)$ nor the interaction between these two factors $(F=1.10 ; D F=6 ; p=0.369)$ (see Figure 1). Among the males, the weight was significantly influenced by stress conditions $(\mathrm{F}=77.88 ; \mathrm{DF}=3 ; \mathrm{p}<0.001)$, by stress time $(\mathrm{F}=9.16 ; \mathrm{DF}=2 ; \mathrm{p}<0.001)$ and by interaction between these two factors $(F=3.96 ; D F=6 ; p<0.005)$ (see Figure 1).

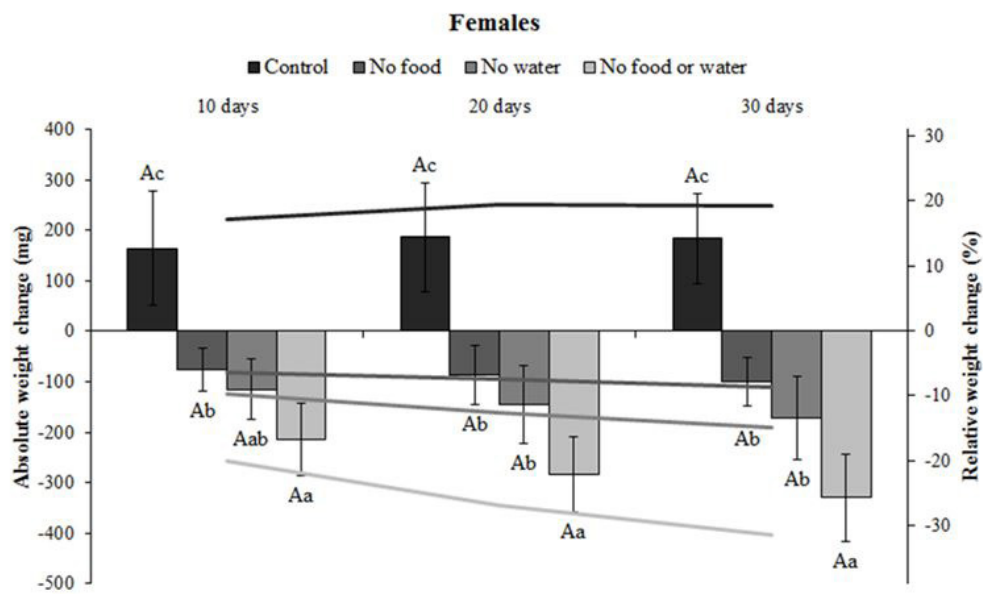

Males

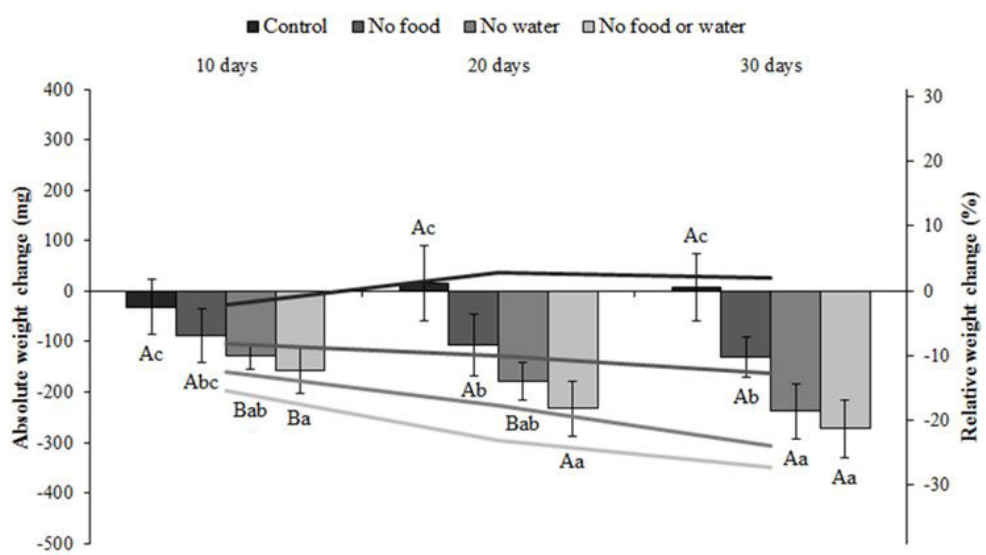

Figure 1. Absolute (mg) and relative (\%) weight change of Periplaneta americana (Linnaeus, 1758) (Blattaria, Blattidae) adults subjected to different stress conditions for different periods. Columns are related to primary vertical axis. Bars represent standard deviation of the mean. Different capital letters represent significant difference between periods, while different small letters represent significant different between stress conditions (Tukey's test $p<0.05$ ). Lines are related to secondary vertical axis. 


\subsection{Weight gain after rehydration}

The weight gain in 24 hours of rehydration after different stress periods was influenced by $\operatorname{sex}(\mathrm{F}=13.33 ; \mathrm{DF}=1$; $\mathrm{p}=0.001)$ and stress time $(\mathrm{F}=30.06 ; \mathrm{DF}=2 ; \mathrm{p}<0.001)$, but it was not influenced by the interaction between these two factors $(\mathrm{F}=0.61 ; \mathrm{DF}=2 ; \mathrm{p}=0.55)$ (see Figure 2$)$.

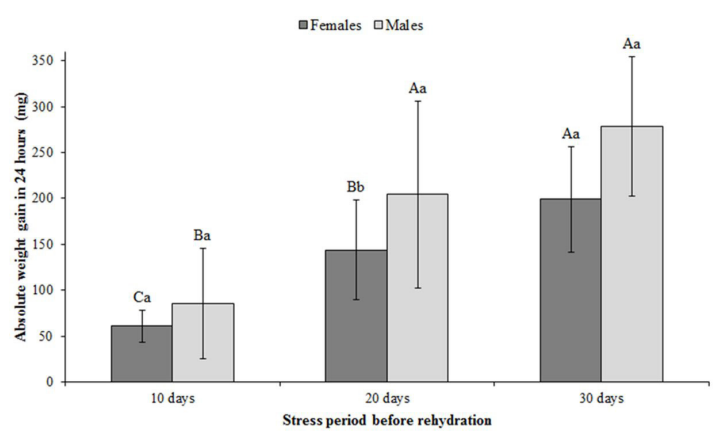

Figure 2. Absolute weight gain (mg) of Periplaneta americana (Linnaeus, 1758) (Blattaria, Blattidae) adults in 24 hours of rehydration after different stress periods with no food and water. Bars represent standard deviation of the mean. Different capital letters represent significant difference between stress periods, while different small letters represent significant different between sexes (Tukey's test $\mathrm{p}<0.05$ ).

\subsection{Total Haemocyte Count (THC) and Differential Haemocyte Count (DHC)}

We were not able to collect haemolymph from insects deprived of water (dehydration and both stresses combined) for 30 days, thus, they were not included in the analyses of the THC and the DHC.

The THC of females was not influenced by stress conditions in $10(\mathrm{~F}=2.01 ; \mathrm{DF}=4 ; \mathrm{p}=0.12), 20(\mathrm{~F}=2.56$; $\mathrm{DF}=4 ; \mathrm{p}=0.06)$ and 30 days $(\mathrm{F}=0.82 ; \mathrm{DF}=2 ; \mathrm{p}=0.45)$ (see Figure 3). Only in the control group the females had a significant decrease in THC related to stress time $(\mathrm{F}=11.18 ; \mathrm{DF}=2 ; \mathrm{p}<0.001)$ (see Figure 3$)$. In the other tested groups, stress time did not influence THC of females (starvation: $\mathrm{F}=0.59 ; \mathrm{DF}=2 ; \mathrm{p}=0.56$; dehydration: $\mathrm{F}=0.99$; $\mathrm{DF}=1 ; \mathrm{p}=0.34$; both stresses: $\mathrm{F}=0.33 ; \mathrm{DF}=1 ; \mathrm{p}=0.58$; both stresses - rehydrated: $F=2.30 ; D F=2 ; p=0.13$ ) (see Figure 3).

The THC of males was not influenced by stress conditions in $10(\mathrm{~F}=0.66 ; \mathrm{DF}=4 ; \mathrm{p}=0.62), 20(\mathrm{~F}=2.56$; $\mathrm{DF}=4 ; \mathrm{p}=0.06)$ and 30 days $(\mathrm{F}=0.32 ; \mathrm{DF}=2 ; \mathrm{p}=0.73)$ (see Figure 3). Stress time did not influence THC of males (control group: $\mathrm{F}=2.16 ; \mathrm{DF}=2 ; \mathrm{p}=0.14$; starvation: $\mathrm{F}=1.03$; $\mathrm{DF}=2 ; \mathrm{p}=0.37$; dehydration: $\mathrm{F}=4.12 ; \mathrm{DF}=1 ; \mathrm{p}=0.06$; both stresses: $\mathrm{F}=1.19 ; \mathrm{DF}=1 ; \mathrm{p}=0.29$; both stresses rehydrated: $\mathrm{F}=1.37 ; \mathrm{DF}=2 ; \mathrm{p}=0.28$ ) (see Figure 3 ).

The significant differences found in the proportion of cell types between different stress conditions and periods were shown in Table 1.

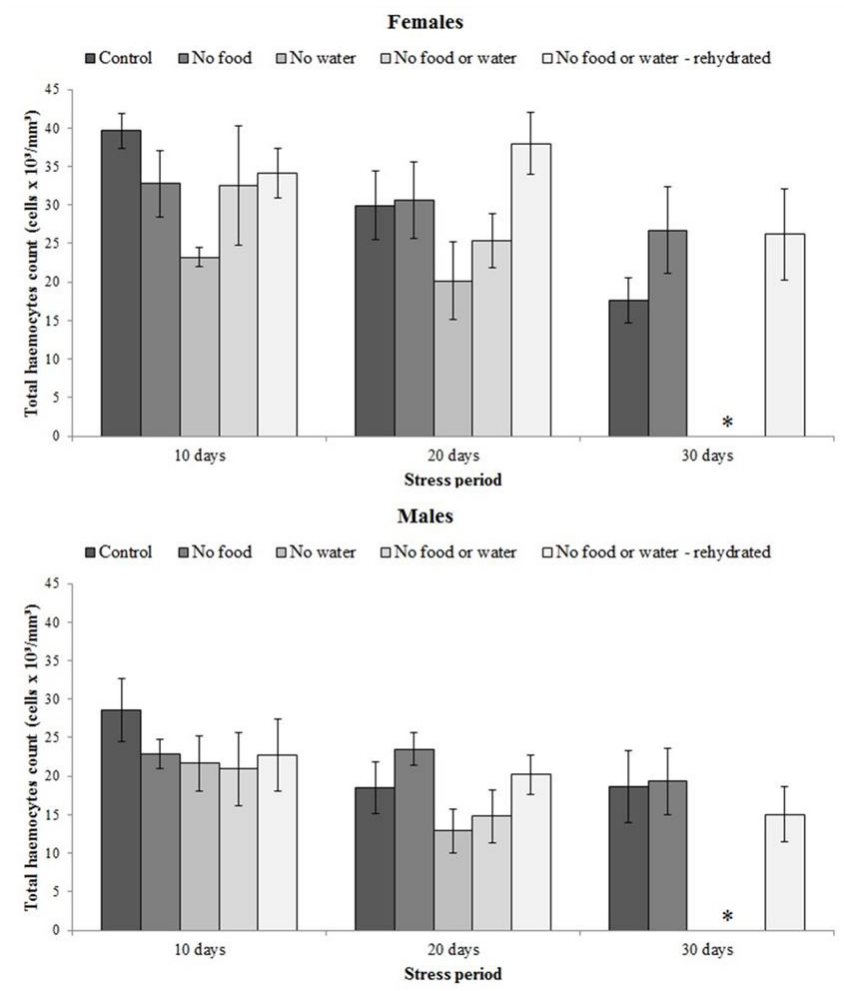

Figure 3. Total haemocyte count (cells $\times 10^{3} / \mathrm{mm}^{3}$ ) of Periplaneta americana (Linnaeus, 1758) (Blattaria, Blattidae) adults subjected to different stress conditions in three different stress periods. Bars represent the standard error of the mean. * We were not able to collect haemolymph from insects with no water (dehydration and stresses combined) for 30 days. 


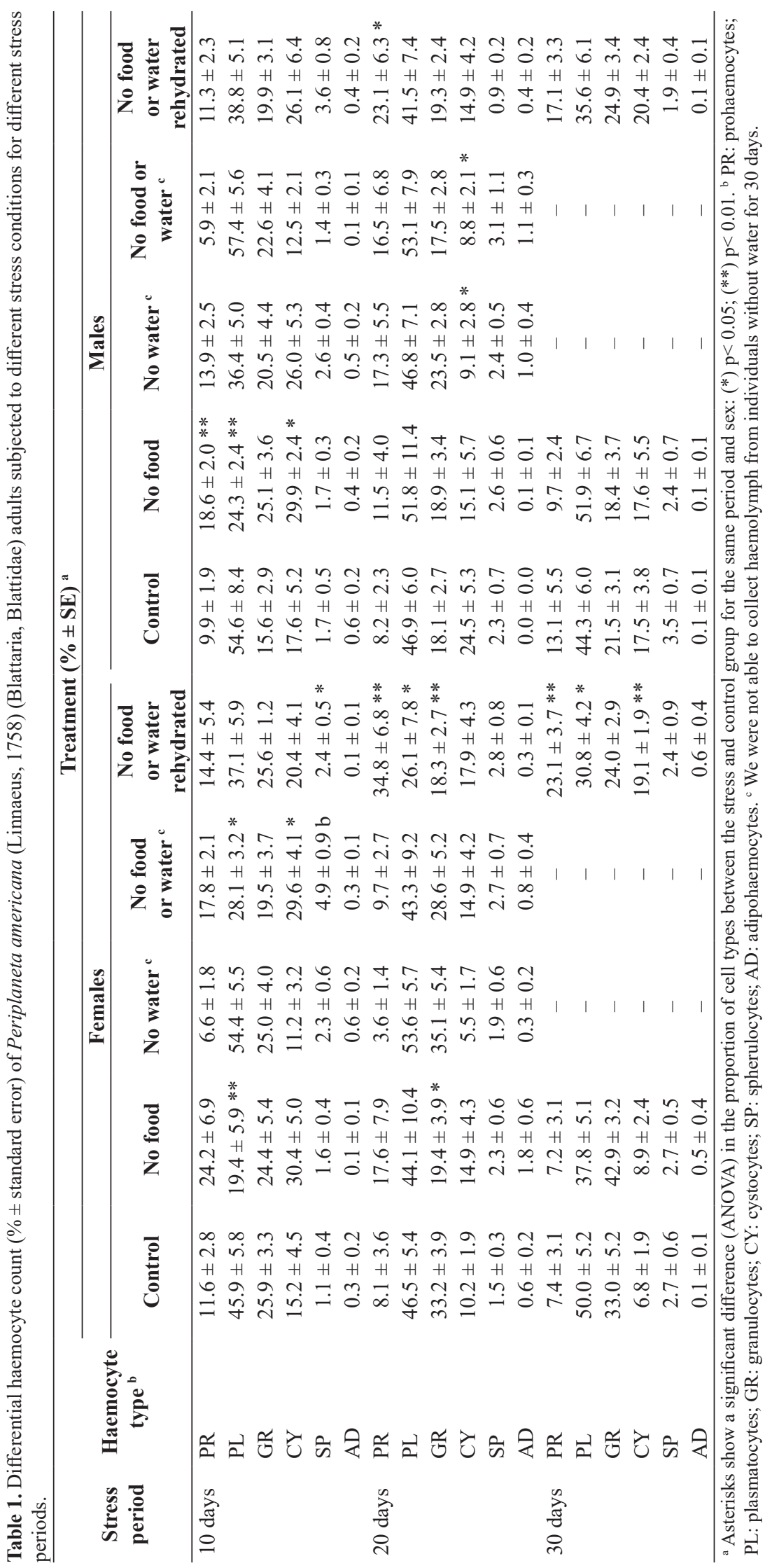




\section{Discussion}

The weight loss in females deprived of food and water for 30 days causes a substantial impact on biology of these insects. As discussed by Duarte et al. (2015), once they lose part of their weight, they can stop oviposition, have their locomotory activity changed and be more susceptible to pathogens and synthetic chemical insecticides. This weight loss was more pronounced in the first ten days of the stress, suggesting that they probably remain active in the beginning of stress, however, after the certain moment, they enter hypobiosis to reduce their energy consumption. This behaviour was described by Grodzicki and Walentynowicz (2011) who affirmed that insects can react by increasing activity rate to find a more comfortable niche or they can reduce their metabolism until enter hypobiosis, in response to extreme impacts.

The fact that females gain more weight than males of the control group is probably due to the need of females to accumulate nutrients in fat bodies to produce ootheca, once Arrese and Soulages (2010) affirmed that the most of the lipids in oocytes are taken from females' fat bodies. The weight gain was also more pronounced in the first ten days, being probably related to the accumulation of nutrients in fat bodies during the pre-oviposition period, because according to Vianna et al. (2011), this period for $P$. americana is about 14 days when raised at $25^{\circ} \mathrm{C}$.

The weight gain in rehydration is supported by Wall (1970), once she reported that cockroaches, when are dehydrated, are capable of drinking the enough to survive for two to three weeks depending on environmental humidity. The positive relation between weight gain from rehydration and stress period is probably due to the fat bodies consumption, providing more space in insect's hemocoel.

The THC found in females of this study are certified by Wheeler (1963), who reported that $P$. americana females with random age have their THC ranging from 23,000 to 127,000 cells $/ \mathrm{mm}^{3}$. However, when comparing with males THC, the author found greater numbers in relation to our work, ranging from 70,000 to 208,000 cells $/ \mathrm{mm}^{3}$.

Only the THC of females deprived of only food was similar to the found by More and Sonawane (1987) when estimate the THC of $P$. americana subjected to these stress types. These authors did not standardize weight, sex and age of the used insects, making hard the comparison of these results.

Although there are reports in different insect species of increasing (Rosenberger and Jones, 1960) and decreasing (Shapiro, 1967) the THC, when they are subjected to absence of food, in this work we did not observe significant changes. The stress period may have not been enough to decrease or increase the THC, since according to Duarte et al. (2015), P. americana adults usually survive more than 48 days with no food or water and they can survive even more if one of these resources is available.

The fact that the THC did not change under these conditions, may be an important mechanism of this species, preserving its immunity in order to survive in its habitats. This species lives in the thrash, bathrooms, sewers and drainage channels (Kaya and Baran, 2015), places with high diversity and abundance of pathogens and parasites, which can cause diseases in insects with weakened immune system.

Even that there is no difference in haemocytes concentration when subjected to stress conditions, the fact that it was not possible to collect haemolymph in insects with no water for 30 days shows a high impact on biology of these insects. According to Klowden (2008), the haemolymph is the main means of transport to exchange materials between cells, like hormones, wastes and nutrients.

In all groups, we observed a tendency of reduction of THC over time, which probably is a characteristic related to the insects' age, since Schmid et al. (2008) reported that Apis mellifera Linnaeus, 1758 (Hymenoptera, Apidae) workers have a decreasing in their THC as they age.

The reduction of plasmatocytes in individuals of both sexes deprived of food for 10 days was also observed by More and Sonawane (1987) for the same species, who reported that plasmatocytes reduced to $30 \%$ of the total count. The same authors also reported that insects deprived of only water did not have changes in the DHC until the 8th day, which was corroborated by the results obtained in this study. This reduction may cause an impact in their survival, once plasmatocytes are one of the main cells involved in phagocytosis, nodulation and encapsulation of pathogens and parasites, as well as they have a role in wound clotting (Lavine and Strand, 2002; Ribeiro and Brehélin, 2006; Klowden, 2008).

The increase of prohaemocytes can be a response of this insect in order to recompose the haemocyte profile after the rehydration. The prohaemocytes are the main cells involved in differentiation into other haemocytes (Lavine and Strand, 2002; Klowden, 2008) and they are the most frequent cells found undergoing mitosis in hematopoietic organs (Gupta, 2009).

In this study, we show that under controlled environmental and alimentary conditions, $P$. americana adults (age, weight and sex standardized) did not present significant changes in the THC or relevant changes in the DHC when subjected to absence of water and/or food for up to 30 days. These findings seem to represent a peculiar characteristic of $P$. americana immune system. Still, we need further studies of defence response of this species.

These data can help the comprehension of the resistance ability of this species when subjected to adversities. It can also serve as a basis of further studies of bioecology, behaviour and the ability of resisting chemical and biological insecticides. Furthermore, it can be important as a model in studies of impact of starvation and dehydration on biology and immunology of other insect species.

\section{Acknowledgements}

The authors thank the Fundação de Amparo à Pesquisa do Estado do Rio Grande do Sul (FAPERGS) (MS scholarships granted to the first author) and the Conselho 
Nacional de Desenvolvimento Científico e Tecnológico (CNPq) (MS and Ph.D. scholarships granted to the last author - under Grant 141796/2010-3).

\section{References}

ARRESE, E.L. and SOULAGES, J.L., 2010. Insect fat body: energy, metabolism, and regulation. Annual Review of Entomology, vol. 55, no. 1, pp. 207-225. http://dx.doi.org/10.1146/annurevento-112408-085356. PMid:19725772.

BAUMHOLTZ, M.A., PARISH, L.C., WITKOWSKI, J.A. and NUTTING, W.B., 1997. The medical importance of cockroaches. International Journal of Dermatology, vol. 36, no. 2, pp. 90-96. http://dx.doi.org/10.1046/j.1365-4362.1997.00077.x. PMid:9109002.

BLOCK, M. and STOKS, R., 2008. Short-term larval food stress and associated compensatory growth reduce adult immune function in a damselfly. Ecological Entomology, vol. 33, no. 6, pp. 796-801. http://dx.doi.org/10.1111/j.1365-2311.2008.01024.x.

BRESSAN-NASCIMENTO, S., OLIVEIRA, D.M.P. and FOX, E.G.P., 2008. Thermal requirements for the embryonic development of Periplaneta americana (L.) (Dictyoptera: Blattidae) with potential application in mass-rearing of egg parasitoids. Biological Control, vol. 47, no. 3, pp. 268-272. http://dx.doi.org/10.1016/j. biocontrol.2008.09.001.

BREY, P.T., 1994. The impact of stress on insect immunity. Bulletin de l'Institut Pasteur, vol. 92, no. 2, pp. 101-118.

CÁRCAMO, M.C., FELCHICHER, F., DUARTE, J.P., KRÜGER, R.F., VIANNA, E.E.S. and RIBEIRO, P.B., 2013. Thermal requirements of Aprostocetus hagenowii (Ratzeburg, 1852) (Hymenoptera, Eulophidae) reared in oothecae of Periplaneta americana (Linnaeus, 1758) (Blattaria, Blattidae). Biotemas, vol. 26, no. 2, pp. 271-275. http://dx.doi.org/10.5007/2175$7925.2013 \mathrm{v} 26 \mathrm{n} 2 \mathrm{p} 271$.

CHALK, R. and SULIAMAN, W.Y. 1998. Antimicrobial peptides from small insects. In: A. WIESNER, ed. Techniques in insect immunology. Fair Haven: SOS Publications, pp. 109-124.

CHAPMAN, R.F. 2013. The insects: structure and function. 5th ed. New York City: Cambridge University Press, 959 p.

DUARTE, J.P., FELCHICHER, F., RIBEIRO, P.B. and CÁRCAMO, M.C., 2015. Survival and weight change among adult individuals of Periplaneta americana (Linnaeus, 1758) (Blattaria, Blattidae) subject to various stress conditions. Biotemas, vol. 28, no. 2, pp. 103-109. http://dx.doi.org/10.5007/2175-7925.2015v28n2p103.

FEDER, D., MELLO, C.B., GARCIA, E.S. and AZAMBUJA, P., 1997. Immune responses in Rhodnius prolixus: influence of nutrition and ecdysone. Journal of Insect Physiology, vol. 43, no. 6, pp. 513-519. http://dx.doi.org/10.1016/S0022-1910(97)000103. PMid:12770413.

FURLONG, M.J. and GRODEN, E., 2003. Starvation induced stress and the susceptibility of the Colorado potato beetle, Leptinotarsa decemlineata, to infection by Beauveria bassiana. Journal of Invertebrate Pathology, vol. 83, no. 2, pp. 127-138. http://dx.doi.org/10.1016/S0022-2011(03)00066-1. PMid:12788282.

GRODZICKI, P. and WALENTYNOWICZ, K. 2011. Hypometabolism in insects. In: A. Nowakowska and M. Caputa, eds. Hypometabolism: strategies of survival in vertebrates and invertebrates. Kerala: Research Signpost, pp. 19-37.
GUPTA, A.P. 2009. Insect hemocytes: development, forms, functions and techniques. Cambridge: Cambridge University Press, 628 p.

KAYA, M. and BARAN, T., 2015. Description of a new surface morphology for chitin extracted from wings of cockroach (Periplaneta americana). International Journal of Biological Macromolecules, vol. 75, pp. 7-12. http://dx.doi.org/10.1016/j. ijbiomac.2015.01.015. PMid:25597430.

KLOWDEN, M.J. 2008. Circulatory systems. In: M.J. Klowden, ed. Physiological systems in insects. San Diego: Academic Press, pp. 357-401. http://dx.doi.org/10.1016/B978-012369493-5.50008-0.

LAVINE, M.D. and STRAND, M.R., 2002. Insect hemocytes and their role in immunity. Insect Biochemistry and Molecular Biology, vol. 32, no. 10, pp. 1295-1309. http://dx.doi.org/10.1016/ S0965-1748(02)00092-9. PMid:12225920.

LORD, J.C., 2010. Dietary stress increases the susceptibility of Tribolium castaneum to Beauveria bassiana. Journal of Economic Entomology, vol. 103, no. 5, pp. 1542-1546. http:// dx.doi.org/10.1603/EC09311. PMid:21061951.

MORE, N.K. and SONAWANE, Y.S., 1987. Stress induced alterations in the hemocyte population of Periplaneta americana (L.). Proceedings of the Indiana Academy of Sciences, vol. 96, no. 6, pp. 689-693. http://dx.doi.org/10.1007/BF03179500.

PANIZZI, A.R. and PARRA, J.R.P. 2009. Introdução à bioecologia e nutrição de insetos como base para o manejo integrado de pragas. In: A.R. Panizzi and J.R.P. Parra, eds. Bioecologia e nutrição de insetos: base para o manejo integrado de pragas. Brasília: Embrapa Informação Tecnológica, pp. 21-35.

RATCLIFFE, N.A. and PRICE, C.D., 1974. Correlation of light and electron microscopic hemocyte structure in the Dictyoptera. Journal of Morphology, vol. 144, no. 4, pp. 485-497. http://dx.doi. org/10.1002/jmor.1051440409. PMid:30314408.

RIBEIRO, C. and BREHÉLIN, M., 2006. Insect haemocytes: what type of cell is that? Journal of Insect Physiology, vol. 52, no. 5, pp. 417-429. http://dx.doi.org/10.1016/j.jinsphys.2006.01.005. PMid:16527302.

RICHARDS, E.H. and EDWARDS, J.P., 1999. Parasitization of Lacania oleracea (Lepidoptera: Noctuidae) by the ectoparasite wasp, Eulophus pennicornis - Effects of parasitization, venom and starvation on host haemocytes. Journal of Insect Physiology, vol. 45, no. 12, pp. 1073-1083. http://dx.doi.org/10.1016/S00221910(99)00091-8. PMid:12770268.

ROSENBERGER, C.R. and JONES, J.C., 1960. Studies on total blood cell counts of the Southern Armyworm larva, Prodenia eridania (Lepidoptera). Annals of the Entomological Society of America, vol. 53, no. 3, pp. 351-355. http://dx.doi.org/10.1093/ aesa/53.3.351.

SCHMID, M.R., BROCKMANN, A., PIRK, C.W.W., STANLEY, D.W. and TAUTZ, J., 2008. Adult honeybees (Apis mellifera L.) abandon hemocytic, but not phenoloxidase-based immunity. Journal of Insect Physiology, vol. 54, no. 2, pp. 439-444. http:// dx.doi.org/10.1016/j.jinsphys.2007.11.002. PMid:18164310.

SHAPIRO, M., 1967. Pathologic changes in the blood of the Greater Wax Moth, Galleria mellonella, during the course of nucleopolyhedrosis and starvation - I. Total hemocyte count. Journal of Invertebrate Pathology, vol. 9, no. 1, pp. 19-25. http:// dx.doi.org/10.1016/0022-2011(67)90050-X.

SIVA-JOTHY, M.T. and THOMPSON, J.J.W., 2002. Short-term nutrient deprivation affects immune function. Physiological 
Entomology, vol. 27, no. 3, pp. 206-212. http://dx.doi.org/10.1046/ j.1365-3032.2002.00286.x.

SUJATHA, P.S. and DUTTA-GUPTA, A., 1991. Feeding and 20-hydroxyecdysone treatment reverses the effect of starvation on total haemocyte count in larval forms of Corcyra cephalonica (Lepidoptera). Journal of Stored Products Research, vol. 27, no. 4, pp. 245-247. http://dx.doi.org/10.1016/0022-474X(91)90007-Y.

VIANNA, E.E.S., BERNE, M.E.A., CHERNAKI, A.M., SILVEIRA JUNIOR, P. and RIBEIRO, P.B., 2000. Performance reprodutiva de Periplaneta americana Linneu, 1758 (Blattodea: Blattidae). Arquivos do Instituto Biológico, vol. 67, no. 1, pp. 99-107.

VIANNA, E.E.S., BERNE, M.E.A. and RIBEIRO, P.B., 2001. Desenvolvimento e longevidade de Periplaneta americana Linneu, 1758 (Blattodea: Blattidae). Revista Brasileira de Agrociência, vol. 7, no. 2, pp. 111-115. http://dx.doi.org/10.18539/cast.v7i2.374.
VIANNA, E.E.S., CÁRCAMO, M.C., DUARTE, J.L.P., ZIMMER, C.R. and RIBEIRO, P.B., 2011. Exigências térmicas de pré-oviposição e incubação para populações de Periplaneta americana Linnaeus, 1758 (Blattaria, Blattidae) da região Sul do Brasil. Revista Brasileira de Zoociências, vol. 13, pp. 49-58.

VIEIRA, S. 2006. Análise de variância (ANOVA). São Paulo: Editora Atlas. 216 p.

WALL, B.J., 1970. Effects of dehydration and rehydration on Periplaneta americana. Journal of Insect Physiology, vol. 16, no. 6, pp. 1027-1042. http://dx.doi.org/10.1016/0022-1910(70)901964. PMid:5469736.

WHEELER, R.E., 1963. Studies on the total haemocyte count and hamolymph volume in Periplaneta americana (L.) with special reference to the last moulting cycle. Journal of Insect Physiology, vol. 9, no. 2, pp. 223-235. http://dx.doi.org/10.1016/00221910(63)90074-X. 